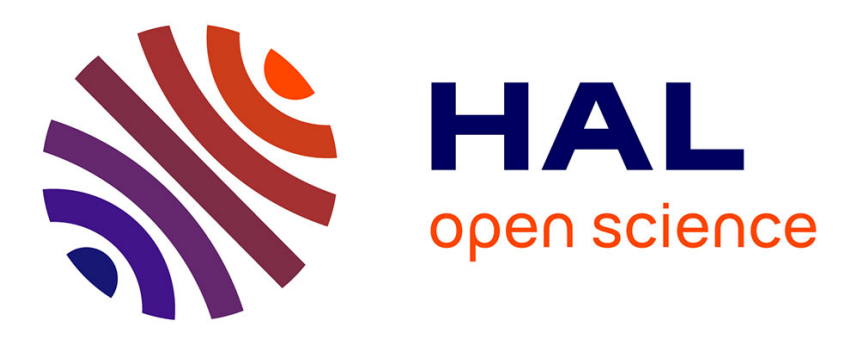

\title{
The GST domain of GDAP1 is a frequent target of mutations in the dominant form of axonal Charcot Marie Tooth type 2K
}

Claudia Crimella, Alessandra Tonelli, Giovanni Airoldi, Cinzia Baschirotto, Maria G d'Angelo, Sara Bonato, Luciana Losito, Antonio Trabacca, Nereo Bresolin, Maria Teresa Bassi

\section{To cite this version:}

Claudia Crimella, Alessandra Tonelli, Giovanni Airoldi, Cinzia Baschirotto, Maria G d'Angelo, et al.. The GST domain of GDAP1 is a frequent target of mutations in the dominant form of axonal Charcot Marie Tooth type 2K. Journal of Medical Genetics, 2010, 47 (10), pp.712. 10.1136/jmg.2010.077909 . hal-00557397

\section{HAL Id: hal-00557397 https://hal.science/hal-00557397}

Submitted on 19 Jan 2011

HAL is a multi-disciplinary open access archive for the deposit and dissemination of scientific research documents, whether they are published or not. The documents may come from teaching and research institutions in France or abroad, or from public or private research centers.
L'archive ouverte pluridisciplinaire HAL, est destinée au dépôt et à la diffusion de documents scientifiques de niveau recherche, publiés ou non, émanant des établissements d'enseignement et de recherche français ou étrangers, des laboratoires publics ou privés. 
The GST domain of GDAP1 is a frequent target of mutations in the dominant form of axonal Charcot Marie Tooth type $2 \mathrm{~K}$

${ }^{1}$ Claudia Crimella, ${ }^{1}$ Alessandra Tonelli, ${ }^{1}$ Giovanni Airoldi, ${ }^{1}$ Cinzia Baschirotto, ${ }^{2}$ Grazia D'Angelo, ${ }^{2}$ Sara Bonato, ${ }^{3}$ Luciana Losito, ${ }^{3}$ Antonio Trabacca, ${ }^{1,4}$ Nereo Bresolin, ${ }^{1}$ Maria Teresa Bassi.

E. Medea Scientific Institute, ${ }^{1}$ Laboratory of Molecular Biology, Bosisio Parini, Italy;

${ }^{2}$ Neuromuscular and Neurorehabilitation Unit, Bosisio Parini, Italy; ${ }^{3}$ E. Medea Scientific Institute, Unit of Neurorehabilitation I, Developmental Neurology and Functional Rehabilitation, Ostuni, Italy; ${ }^{4}$ Dino Ferrari Centre, IRCCS Ca' Granda, Ospedale Maggiore Policlinico Foundation, Dept. of Neurological Sciences University of Milan, Italy.

Word count: 2341

Key words: GDAP1, heterozygous mutations, CMT2K, GST domain

Corresponding Author: Maria Teresa Bassi, PhD, Laboratory of Molecular Biology, E. Medea Scientific Institute, Via D. L. Monza 20, 23842 Bosisio Parini, Lecco, Italy; Phone 0039 031877111, Fax 0039031877499 , email: mariateresa.bassi@bp.lnf.it. 


\begin{abstract}
Background: Mutations in GDAPl associate with both demyelinating (CMT4A) and axonal (CMT2K) forms of CMT. While CMT4A shows recessive inheritance, CMT2K can present with either recessive (AR-CMT2K) or dominant segregation pattern (AD-CMT2K), the latter being characterized by milder phenotypes and later onset. The majority of the GDAP1 mutations are associated with CMT4A and AR-CMT2K, with only 4 heterozygous mutations identified in ADCMT2K.

Methods: We screened GDAP1 gene in a series of 43 index patients, 39 with CMT2 and 4 with intermediate CMT, with both sporadic and familial occurrence of the disease. Results: Three novel mutations were identified in three families with dominant segregation of the disease: two missense changes, p.Arg226Ser and p.Ser34Cys, affecting the GST domain of the GDAP1 protein and a novel deletion (c.23delAG) leading to early truncation of the protein upstream the GST domain. Wide variability in clinical presentation is shared by all three families mostly in terms of age at onset and disease severity. A rare variant p.Gly269Arg, located within the GST domain, apparently acts as phenotype modulator in the family carrying the deletion. Conclusion: The results obtained reveal a GDAPl mutation frequency of $27 \%$ in the dominant families analyzed, a figure still unreported for this gene, thus suggesting that GDAP1 involvement in dominant CMT2 might be higher than expected.
\end{abstract}

\title{
Introduction
}

Charcot-Marie Tooth disease (CMT) is an heterogeneous group of diseases characterized by chronic motor and sensory polyneuropathy leading to progressive loss of sensation, weakness, muscle atrophy, loss of deep tendon reflexes and foot deformities. CMT can be classified in two major subtypes: demyelinating CMT (CMT1, CMT4), associated with reduction in nerve conduction velocities (NCV) in all nerves and segmental demyelination and remyelination; and axonal CMT (CMT2) associated with normal or almost normal NCVs, loss of myelinated axons and regenerative sprouting. A CMT subgroup showing NCV values "intermediate" between CMT1 and CMT2 also exists. Mutations in the ganglioside-induced differentiation-associated protein 1 (GDAP1) gene are responsible for an autosomal recessive (AR) severe demyelinating form called CMT type 4A (OMIM 214400) [1,2], and axonal forms with [2], or without vocal cord paralysis (AR-CMT2K OMIM 607831) [3,4]. Mutations in this gene were found also in few family with a late-onset dominant form of CMT (AD-CMT2K) [5-7] and in patients presenting with a mixed phenotype including both axonal and demyelinating aspects [8]. 
AR-CMT patients with GDAPl mutations, show a severe phenotype characterized by a rapidly progressive weakness, usually beginning before the age of 3 years and eventually leading to inability to walk by the second or third decade. This phenotype can include vocal cord paresis, diaphragmatic paralysis, or kyphoscoliosis [9-12]. The dominant form is characterized by a much milder phenotype and onset during the second decade of life [5-7] with signs of axonal degeneration and demyelination at the histopathologic examination [6]. The majority of GDAP1 mutations are associated with recessive CMT4A and with AR-CMT2K while only 4 were found in dominant CMT2K cases [5-7]. Few large GDAP1 mutation screenings were conducted so far, and only in mixed population with both demyelinating and axonal AR-CMT patients [5,13]. GDAP1 mutation frequency in axonal CMT (CMT2) is not known.

GDAP1 is a 358 amino acid protein belonging to a new subfamily of the glutathione-S-transferases (GST), a large family of enzymes sharing structural and functional similarities [1,2]. Most of these proteins are responsible for the metabolism of many compounds via conjugation with reduced glutathione. GDAP1 is located in the mitochondrial outer membrane, and unlike other GST enzymes, acts as mitochondrial fission factor regulating the mitochondrial network dynamics [1417]. Recently, it was demonstrated that recessive GDAP1 mutations are associated with reduced fission activity while dominant mutations impair mitochondrial fusion and cause mitochondrial damage [18].

We report the results of a GDAP1 mutation analysis performed in 43 selected index patients affected by CMT2 (39) or an intermediate form of CMT (4), and negative for mutations in the genes most frequently involved in these forms. Of note, $27 \%$ of the dominant cases tested carry novel heterozygous mutations in this gene, an unexpected high percentage considering the low number of GDAP1 heterozygous mutations reported so far. The genetic and clinical implications of these findings are discussed.

\section{Patients and Methods}

Forty three unrelated index patients from 43 families (total number of patients, 56) with a clinical diagnosis of axonal neuropathy were clinically and genetically analyzed. Thirty nine presented with a CMT2 phenotype with median nerve conduction velocities (MNCV) of $38 \mathrm{~m} / \mathrm{s}$ or greater while 4 presented an "intermediate CMT" phenotype with slightly reduced MNCV (from 25 to 38m/s). All showed severely reduced amplitudes of the compound motor and sensory nerve action potentials (or absent in some cases). Vocal cord paralysis with hoarseness or pyramidal signs were present in one and five sporadic cases respectively. 
Twenty nine were sporadic (including the intermediate CMT) while 14 were familial cases, 11 with dominant segregation pattern of the disease while 3 were from recessive pedigrees. In one of the dominant families, P1086, the dominant inheritance is inferred by the clinical records of the proband' mother since she was not available to the authors for any clinical or genetic evaluation. Patients from recessive families and the proband of one of the dominant families (P227) had early onset (2-3 years of age) and severe disease status; almost all of them where wheelchair dependent by the age of 18 years. In all other patients, disease onset was in the age range of 7-20 years with the exception of 4 who had onset in the thirties, with a generally mild course with few exceptions. All patients were of Italian origin, 65\% from the Northern part of the country, while $45 \%$ were from the South; all were in charge of the three Neurology services indicated in the affiliations. For all patients, mutations in $M P Z, M F N 2, H S P B 1, H S P B 8, C x 32$ and NEFL were previously excluded. GARS, YARS and BSCL2 mutations were also excluded in all patients presenting with pyramidal features. The study was approved by the ethical committee of the E. Medea Scientific Institute. Blood specimens were obtained after informed consent. Genomic DNA from peripheral blood leukocytes was prepared with the standard high salt extraction method. GDAPl genomic region is available at the Human Genome Browser Gateway (http://genome.ucsc.edu/cgibin/hgGateway). All 6 exons of the GDAP1 gene were amplified and mutation analysis was performed by sequencing of all exons with a Big Dye Terminator Sequencing Kit (version 3.1 Applied Biosystem Foster City, CA, USA). Mutation nomenclature is based on RefSeq NM_018972.2 [GenBank] (considering the A of the ATG as nt 1) and on Ref Seq NC_000008.9 for GDAP1 cDNA and genomic sequences respectively, and follows the guidelines of the Human Genome Variation Society (http://www.hgvs.org/mutnomen/). Five hundreds healthy individuals from the Italian population were used as controls. Missense changes were analysed with SIFT ( http://blocks.fhcrc.org/sift) and Polyphen (http://genetics.bwh.harvard.edu/pph/) softwares.

\section{Results}

Mutation screening of GDAPl gene was performed in this series of 43 index patients, 39 with CMT2 and 4 with intermediate form of CMT with either familial or sporadic occurrence. The analysis revealed 3 novel heterozygous mutations in 3 families out of 11 with dominant inheritance of the disease (figure 1A). Clinical and electrophysiological data of the patients carrying GDAP1 mutations, are summarized in Table 1 while a detailed description is provided as supplementary material (S1). Remarkably, in all three families symptoms onset was in the first decade in the probands while in the thirties (P227, P197) or twenties (P1086) in the carrier parents. Disease severity among the probands was also variable, with the most severe clinical picture and loss of 
ambulation at $18 \mathrm{yrs}$, in the proband of family P227 who showed also the earliest onset ( $3 \mathrm{yrs}$ ). No pyramidal signs or vocal cord paralysis are present in any of the affected members of these families.

Table 1 Clinical and electrophysiological findings in three Italian families with heterozygous GDAP1 mutations.

\begin{tabular}{|c|c|c|c|c|c|c|}
\hline Patient ID & P197/ II-I & P197/I-I & P227/II-I & P227/I-I & P1086/III-I & P1086/II-II \\
\hline Age at onset/gender & $8 y \mathrm{ys} / \mathrm{F}$ & $35 \mathrm{ys} / \mathrm{F}$ & 3ys/F & $30 \mathrm{ys} / \mathrm{F}$ & $7 \mathrm{ys} / \mathrm{F}$ & $20 \mathrm{ys} / \mathrm{F}$ \\
\hline Involved limb at onset & lower limbs & lower limbs & $\begin{array}{l}\text { upper and lower } \\
\text { limbs }\end{array}$ & lower limbs (EMG) & lower limbs & lower limbs \\
\hline $\begin{array}{l}\text { Age at last evaluation } \\
\text { (years) }\end{array}$ & 25 ys & 49 ys & $24 \mathrm{ys}$ & 53 ys & 20 ys & $20 y s$ \\
\hline $\begin{array}{l}\text { Clinical involvement } \\
\text { at last examination }\end{array}$ & $\begin{array}{c}\text { foot paralysis, } \\
\text { weakness small } \\
\text { hand muscles++ }\end{array}$ & $\begin{array}{l}\text { no clinical } \\
\text { signs, } \\
\text { only EMG }\end{array}$ & $\begin{array}{l}\text { foot paralysis and } \\
\text { complete bilateral } \\
\text { small hand muscle } \\
\text { paralysis }\end{array}$ & $\begin{array}{l}\text { lower limb weakness, } \\
\text { mild vibration sense } \\
\text { deficit }\end{array}$ & $\begin{array}{l}\text { distal lower } \\
\text { limbs severe } \\
\text { muscular } \\
\text { atrophy and } \\
\text { upper limbs } \\
\text { mild muscular } \\
\text { hypotrophy; } \\
\text { complete } \\
\text { bilateral foot } \\
\text { paralysis with } \\
\text { a moderate } \\
\text { weakness of } \\
\text { the proximal } \\
\text { muscles; mild } \\
\text { weakness in } \\
\text { the small hand } \\
\text { muscles }\end{array}$ & $\begin{array}{l}\text { slowly distal } \\
\text { lower limbs } \\
\text { weakness with } \\
\text { associated mild } \\
\text { hypotrophy }\end{array}$ \\
\hline Walking ability & $\begin{array}{c}\text { walks } \\
\text { independently }\end{array}$ & $\begin{array}{c}\text { walks } \\
\text { independently }\end{array}$ & lost at 18 ys & walks independently & $\begin{array}{l}\text { possible only } \\
\text { with prothesis }\end{array}$ & $\begin{array}{c}\text { walks } \\
\text { independently }\end{array}$ \\
\hline Others & & & & $\begin{array}{l}\text { dysthyroidism- } \\
\text { arythmias }\end{array}$ & $\begin{array}{l}\text { esophageal } \\
\text { achalasia }\end{array}$ & \\
\hline \multicolumn{7}{|l|}{$\begin{array}{l}\text { Motor nerve conduction } \\
\text { velocity }(\mathrm{m} / \mathrm{s})\end{array}$} \\
\hline ulnar (vn 46,5-72,6) & 48,9 & NA & 47 & NA & 54,2 & NA \\
\hline tibial $(39,8-66,9)$ & 27 & 45 & 25 & 42 & absent & NA \\
\hline \multicolumn{7}{|l|}{$\begin{array}{c}\text { Sensory nerve conduction } \\
\text { velocity }(\mathrm{m} / \mathrm{s})\end{array}$} \\
\hline median $(36,5-65)$ & 45,8 & 51 & 44,5 & 54 & absent & NA \\
\hline sural $(35,6-63,6)$ & 31,2 & 40 & 28,8 & 39 & absent & NA \\
\hline \multicolumn{7}{|l|}{ CMAP mV } \\
\hline tibial nerve & 3,5 & 6,8 & 3 & 5,6 & absent & NA \\
\hline peroneal nerve & 0,3 & 10,9 & 1 & 7 & absent & NA \\
\hline \multicolumn{7}{|l|}{$\mathbf{S A P} \mu \mathbf{V}$} \\
\hline sural nerve & 4,9 & 10 & 4 & 7 & absent & NA \\
\hline median nerve & 4 & 9 & 3 & 9 & absent & NA \\
\hline
\end{tabular}

CMAP: compound motor action potential; NA: not assessed; SAP: sensory action potential. 
A nucleotide change c.678A>T in exon 5 was found in the proband of family P197, (figure 1A), leading to the missense mutation p.Arg226Ser. This mutation was inherited from the mother (P197 I-1) presenting only an abnormal electromyography (Table 1), while was absent in the healthy father and in 500 controls. The mutant residue is located within the GST domain of GDAP1 protein, in the $\alpha$-helix $5(\alpha 5)$ within the $\alpha$-motif II (figure $1 \mathrm{~B}$ ) and is highly conserved throughout evolution (figure 1S).

The proband of P1086 family carried a mutation in exon 1, c.101C >G leading to the missense change p.Ser34Cys (figure 1A). The mutant residue is located within the GST core region, two amino acids upstream the $\alpha$-helix structure and is highly conserved (figure 1S). Only the healthy father was available for genetic analysis and was negative.

In family P227, the proband carried a heterozygous deletion in exon 1 (c.23delAG) leading to a frameshift and early protein interruption (p.Gly10GlufsX14) (figure 1A). A nucleotide change in exon 6 c.805G>A, was also detected causing the p.Gly269Arg substitution. While the deletion is inherited from the affected mother, the missense variation was detected in the unaffected father and in two out of 500 controls (allele freq 0.2).

Analysis of all missense changes found with SIFT and Polyphen softwares indicates that p.Arg226Ser and p.Ser34Cys are both predicted to damage protein structure and affect protein function (figure 1A). The p.Gly269Arg substitution is instead compatible with normal protein function for both programs. Its location, far from the $\alpha$-helix structure, and the segregation pattern both favour the hypothesis of p.Gly269Arg being a rare missense variant.

\section{Discussion}

We report the results of a GDAP1 mutations screening performed in 39 CMT2 and 4 intermediate CMT patients, with either sporadic or familial occurrence. While no mutations were observed in sporadic or recessive patients, 3 novel heterozygous GDAP1 mutations were found in 3 out of 11 dominant families. This result leads to a GDAP1 mutations frequency of $27 \%$ in AD-CMT2, a figure so far unreported for GDAP1. A similar frequency is known for MFN2 which is responsible for $17-33 \%$ of dominant cases with CMT2 [19,20]. Although the GDAP1 mutation frequency we observed needs to be confirmed in larger series of patients, the results obtained suggest that GDAP1 involvement in AD-CMT2 might be higher than expected. In fact only four heterozygous mutations were reported so far in this form [5-7]. Ethnic origin and geographical distribution of the patients here tested per se, hardly account for the high GDAP1 mutation frequency observed. Our families carrying a GDAPl mutation are all from different Italian regions. It is more likely that the 
preliminary exclusion of mutations in the genes more frequently involved in CMT2 in the patients here tested might have partly contributed to this unexpected result. The lack of mutations observed in our group of sporadic patients compared to a known frequency of 5,6\% [5] might be explained both by the lower sample size (29 vs 106) and by the different types of patients samples in the two studies: only axonal CMT patients in this study compared with mixed axonal and demyelinating patients in the previous one.

The AD-CMT2K phenotype described in previous reports was mild with disease onset in the second or third decade and a mild course. The clinical picture emerging from the families here described partly overlaps to that phenotype with a marked intra- and inter-familial variability, mostly in disease severity and symptoms onset. Indeed, in all three families symptoms onset was in the first decade in the probands while in the thirties (P227, P197) or twenties (P1086) in the carrier parents. In P227 II-1, the age at disease onset is very early (3 years). Unexpectedly in the carrier mother (P227 I-1), the disease is manifesting in a very mild form with only subclinical signs in the thirties, then evolving to mild clinical symptoms only in the late forties. Disease severity is also apparently directly correlated with the age at disease onset, with the most severe clinical picture (loss of ambulation at 18 yrs) displayed by the patient with the earliest onset (P227 II-1).

The majority of the GDAP1 mutations associated with AD-CMT2K, affect the GST domain, the hallmark of the glutathione S-transferases (GSTs), enzymes that have a role in the detoxification of cells. GDAP1 belongs to a new subfamily of GSTs [2,21] for which no GST activity was proved so far [21]. It was instead demonstrated to regulate mitochondrial network by promoting mitochondrial fission rather than detoxifying reactive oxygen species [14]. The GST domain lies within the cytoplasmic N-terminal region with two motifs: motif I that corresponds to the glutathione binding site (aa 26-119) in which the aminoacid residues have a secondary structure $\beta \alpha \beta \alpha \beta \beta \alpha$, and the $\alpha$ motif II (aa 210-287) associated with presumed xenobiotic and cytotoxic activities [2]. All known mutation associated with the AD-CMT2K phenotype fall within the two motifs with the exception of one p.Thr157Pro, falling in the region between the two. With regard to the novel heterozygous mutations here reported, c.23delAG is truncating at the N-terminus just upstream the GST domain, p.Ser34Cys lies within the GST domain just upstream the $\alpha$-helix 1 while p.Arg226Ser falls within the $\alpha$-helix 5. The two novel missense changes are both predicted to have a damaging effect by using two prediction softwares (figure 1A) and both affect evolutionary conserved residues (figure 1S). In particular Serine 34 residue represents the catalytically active residue positioned at the Nterminal of $\alpha-1$ in the thioredoxin domain, which is shared by all enzymatically active GSTs [22]. The mutant cysteine residue (C34) is shared only by the omega class of GSTs [21] that had been 
shown to have poor GST activity with common substrates being rather involved in $\mathrm{Ca}^{2+}$-release modulation through ryanodine receptors (RYR1) [23].

Although no GST activity was demonstrated so far for GDAP1 [22], based on the mutations results in AD-CMT2K patients reported here and elsewhere, GST domain turns out to be a frequent target for mutations in AD-CMT2K. This suggests that whatever is the function associated with this domain, this has to be relevant in the pathogenesis of AD-CMT2K disease. In addition, targeting of all mutations to the $\alpha$-helices of the GST domain suggests that the $\alpha$-helices integrity is also a strong structural requirement for GDAP1 activity to be performed.

Three of the four known mutations associated with AD-CMT2K, p.Arg210Trp, p.Thr157Pro, p.Gln218Glu, were in fact demonstrated to impair mitochondrial fusion leading to elevated ROS levels and to increase susceptibility to apoptosis [18]. According to the authors' predictions [18], an analogous deleterious gain of function can be also postulated for other dominant missense mutations with shared location such those here reported. By contrast, the heterozygous two-bpdeletion described here, leading to early protein truncation (p.Gly10GlufsX14) and therefore to a likely loss of function, is in fact associated with a very mild phenotype (see the carrier mother in family P227). The additional presence of the heterozygous variant p.Gly269Arg (still in the $\alpha$-motif II of the GST domain) in the proband P227 II-1, associates with a more dramatic effect on clinical phenotype (Table 1). Since this missense variant by itself is not associated with a pathological phenotype, p.Gly269Arg may have a role as phenotype modulator with an allele frequency in the Italian population of $0,2 \%$.

From a different point of view, overall the results obtained provide some more clues of clinical and diagnostic value for AD-CMT2K, mostly underlying the variable penetrance and different clinical expressivity associated with all mutations identified. Although with the limitation due to the relatively small sample size, these data also suggest the opportunity to screen GDAP1 gene in autosomal dominant patients with CMT2, negative for mutations in MFN2 gene.

\section{Acknowledgements}

The Authors wish to thank patients and their families for participation to the study. The work was supported by the Italian Ministry of Health, grant n RF2007-75 (MTB, NB, MGD), RC2008-2009, ex Art56 PSNEURO 8 (MTB, NB, MGD), Cariplo Foundation grant \# 2007.5156 (MTB).

The Authors declare no competing interests. The Corresponding Author has the right to grant on behalf of all authors and does grant on behalf of all authors, an exclusive licence on a worldwide basis to the BMJ Publishing Group Ltd and its Licensees to permit this article (if accepted) to be 
published in JMG and any other BMJPGL products to exploit all subsidiary rights, as set out in JMG licence (http://jmg.bmj.com/ifora/licence.pdf)."

\section{References}

1. Baxter RV, Ben Othmane K, Rochelle JM, Stajich JE, Hulette C, Dew-Knight S, Hentati F, Ben Hamida M, Bel S, Stenger JE,Gilbert JR, Pericak-Vance MA, Vance JM. Ganglioside-induced differentiation-associated protein-1 is mutant in Charcot-Marie-Tooth disease type 4A/8q21. Nat Genet 2002; 30(1):21-22.

2. Cuesta A, Pedrola L, Sevilla T, García-Planells J, Chumillas MJ, Mayordomo F, LeGuern E, Marín I, Vílchez JJ, Palau F. The gene encoding ganglioside-induced differentiation-associated protein 1 is mutated in axonal Charcot-Marie-Tooth type 4A disease. Nat Genet 2002; 30(1):22-25. 3. Nelis E, Erdem S, Van Den Bergh PY, Belpaire-Dethiou MC, Ceuterick C, Van Gerwen V, Cuesta A, Pedrola L, Palau F, Gabreëls-Festen AA, Verellen C, Tan E, Demirci M, Van Broeckhoven C, De Jonghe P, Topaloglu H, Timmerman V. Mutations in GDAP1: autosomal recessive CMT with demyelination and axonopathy. Neurology 2002; 59(12):1865-1872.

4. Calapoglu NF, Tan M, Soyoz M, Calapoglu M, Ozcelik N. Novel GDAP1 mutation in a Turkish family with CMT2K (CMT2K with novel GDAP1 mutation). Neuromol Med 2009; 11 :106-113.

5. Claramunt R, Pedrola L, Sevilla T, López de Munain A, Berciano J, Cuesta A, Sánchez-Navarro B, Millán JM, Saifi GM, Lupski JR, Vílchez JJ, Espinós C, Palau F. Genetics of Charcot-MarieTooth disease type 4A: mutations, inheritance, phenotypic variability, and founder effect. $J$ Med Genet 2005; 42(4):358-365.

6. Chung KW, Kim SM, Sunwoo IN, Cho SY, Hwang SJ, Kim J, Kang SH, Park KD, Choi KG, Choi IS, Choi BO. 2008. A novel GDAP1 Q218E mutation in autosomal dominant Charcot-MarieTooth disease. J Hum Genet 53(4):360-364.

7. Cassereau J, Chevrollier A, Gueguen N, Malinge MC, Letournel F, Nicolas G, Richard L, Ferre M, Verny C, Dubas F, Procaccio V, Amati-Bonneau P, Bonneau D, Reynier P. Mitochondrial complex I deficiency in GDAP1-related autosomal dominant Charcot-Marie-Tooth disease (CMT2K). Neurogenetics 2009; 10(2):145-150. 
8. Senderek J, Bergmann C, Ramaekers VT, Nelis E, Bernert G, Makowski A, Züchner S, De Jonghe P, Rudnik-Schöneborn S, Zerres K , Schröder JM. 2003. Mutations in the gangliosideinduced differentiation-associated protein-1 (GDAP1) gene in intermediate type autosomal recessive Charcot-Marie-Tooth neuropathy. Brain 2003; 126(Pt 3):642-9.

9. Birouk N, Azzedine H, Dubourg O, Muriel MP, Benomar A, Hamadouche T, Maisonobe T, Ouazzani R, Brice A, Yahyaoui M, Chkili T, Le Guern E. Phenotypical features of a Moroccan family with autosomal recessive Charcot-Marie-Tooth disease associated with the S194X mutation in the GDAP1 gene. Arch Neurol 2003; 60(4):598-604.

10. Stojkovic T, Latour P, Viet G, de Seze J, Hurtevent JF, Vandenberghe A, Vermersch P. Vocal cord and diaphragm paralysis, as clinical features of a French family with autosomal recessive Charcot-Marie-Tooth disease, associated with a new mutation in the GDAP1 gene. Neuromuscul Disord 2004; 14(4):261-264.

11. Bernard R, De Sandre-Giovannoli A, Delague V, Lévy N. Molecular genetics of autosomalrecessive axonal Charcot-Marie-Tooth neuropathies. Neuromolecular Med 2006; 8(1-2):87-106.

12. Sevilla T, Jaijo T, Nauffal D, Collado D, Chumillas MJ, Vilchez JJ, Muelas N, Bataller L, Domenech R, Espinós C, Palau F. Vocal cord paresis and diaphragmatic dysfunction are severe and frequent symptoms of GDAP1-associated neuropathy. Brain 2008; 131(Pt 11):3051-3061.

13. Di Maria E, Gulli R, Balestra P, Cassandrini D, Pigullo S, Doria-Lamba L, Bado M, Schenone A, Ajmar F, Mandich P, Bellone E. A novel mutation of GDAP1 associated with Charcot-MarieTooth disease in three Italian families: evidence for a founder effect. J Neurol Neurosurg Psychiatry 2004; 75(10):1495-8.

14. Niemann A, Ruegg M, La Padula V, Schenone A, Suter U. Ganglioside-induced differentiation associated protein 1 is a regulator of the mitochondrial network: new implications for CharcotMarie-Tooth disease. J Cell Biol 2005; 170(7):1067-1078.

15. Niemann A, Berger P, Suter U. Pathomechanisms of mutant proteins in Charcot-Marie-Tooth disease. Neuromolecular Med 2006; 8(1-2):217-242.

16. Pedrola L, Espert A, Wu X, Claramunt R, Shy ME, Palau F. GDAP1, the protein causing Charcot Marie-Tooth disease type 4a, is expressed in neurons and is associated with mitochondria. Hum Mol Genet 2005; 14(8):1087-1094.

17. Pedrola L, Espert A, Valdés-Sánchez T, Sánchez-Piris M, Sirkowski EE, Scherer SS, Fariñas I, Palau F. Cell expression of GDAP1 in the nervous system and pathogenesis of Charcot-MarieTooth type 4A disease. J Cell Mol Med 2008; 12(2):679-689. 
18. Niemann A, Wagner KM, Ruegg M, Suter U. GDAP1 mutations differ in their effects on mitochondrial dynamics and apoptosis depending on the mode of inheritance. Neurobiol Dis 2009; 36(3):509-520.

19. Verhoeven K, Claeys KG, Züchner S, Schröder JM, Weis J, Ceuterick C, Jordanova A, Nelis E, De Vriendt E, Van Hul M, Seeman P, Mazanec R, Saifi GM, Szigeti K, Mancias P, Butler IJ, Kochanski A, Ryniewicz B, De Bleecker J, Van den Bergh P, Verellen C, Van Coster R, Goemans N, Auer-Grumbach M, Robberecht W, Milic Rasic V, Nevo Y, Tournev I, Guergueltcheva V, Roelens F, Vieregge P, Vinci P, Moreno MT, Christen HJ, Shy ME, Lupski JR, Vance JM, De Jonghe P, Timmerman V. MFN2 mutation distribution and genotype/phenotype correlation in Charcot-Marie-Tooth type 2. Brain 2006; 129(Pt 8):2093-2102.

20. Calvo J, Funalot B, Ouvrier RA, Lazaro L, Toutain A, De Mas P, Bouche P, Gilbert-Dussardier B, Arne-Bes MC, Carrière JP, Journel H, Minot-Myhie MC, Guillou C, Ghorab K, Magy L, Sturtz F, Vallat JM, Magdelaine C. Genotype-phenotype correlations in Charcot-Marie-Tooth disease type 2 caused by mitofusin 2 mutations. Arch Neurol 2009; 66(12):1511-1516.

21. Marco A, Cuesta A, Pedrola L, Palau F, Marín I. Evolutionary and structural analyses of GDAP1, involved in Charcot-Marie-Tooth disease, characterize a novel class of glutathione transferase-related genes. Mol Biol Evol 2004; 21(1):176-187.

22. Shield AJ, Murray TP, Board PG. Functional characterisation of ganglioside-induced differentiation-associated protein 1 as a glutathione transferase. Biochem Biophys Res Commun 2006; 347(4):859-866.

23. Whitbread AK, Tetlow N, Eyre HJ, Sutherland GR, Board PG. Characterization of the human Omega class glutathione transferase genes and associated polymorphysms. Pharmacogenetics 2003; 13(3):131-144. 


\section{Figure Legend}

Figure 1: A. The pedigree of families with GDAP1 mutations; dyamond symbols are for anonymity reasons, stars and arrows indicate subjects whose DNA is available and probands respectively. Elechtropherograms show the mutant sequences and the corresponding controls. Boxed sequences are either the mutant nucleotide (P197, P1086) or the deleted sequence (P227). The arrowhead in pedigree P227 shows the deletion site; $\Delta$-allele indicates the subcloned deleted allele. On the right SIFT and Polyphen software's prediction are summarized. With SIFT program the score ranges from 0 to 1 , where 0 is damaging and 1 is neutral. Polyphen's score ranges from 0 to a positive number, where 0 is neutral and a high positive number is damaging. For the exonic variant p.Gly269Arg the SIFT's protein prediction is 0.11 (tolerated); Polyphen's prediction is 1.501 (possibly damaging).

B. Schematic representation of GDAP1 protein domains with the heterozygous mutations identified; the novel ones are circled. The dashed bars below indicate the two motifs constituting the glutathione S-transferases domain. HD1: hydrophobic domain 1; TMD:transmembrane domain. 

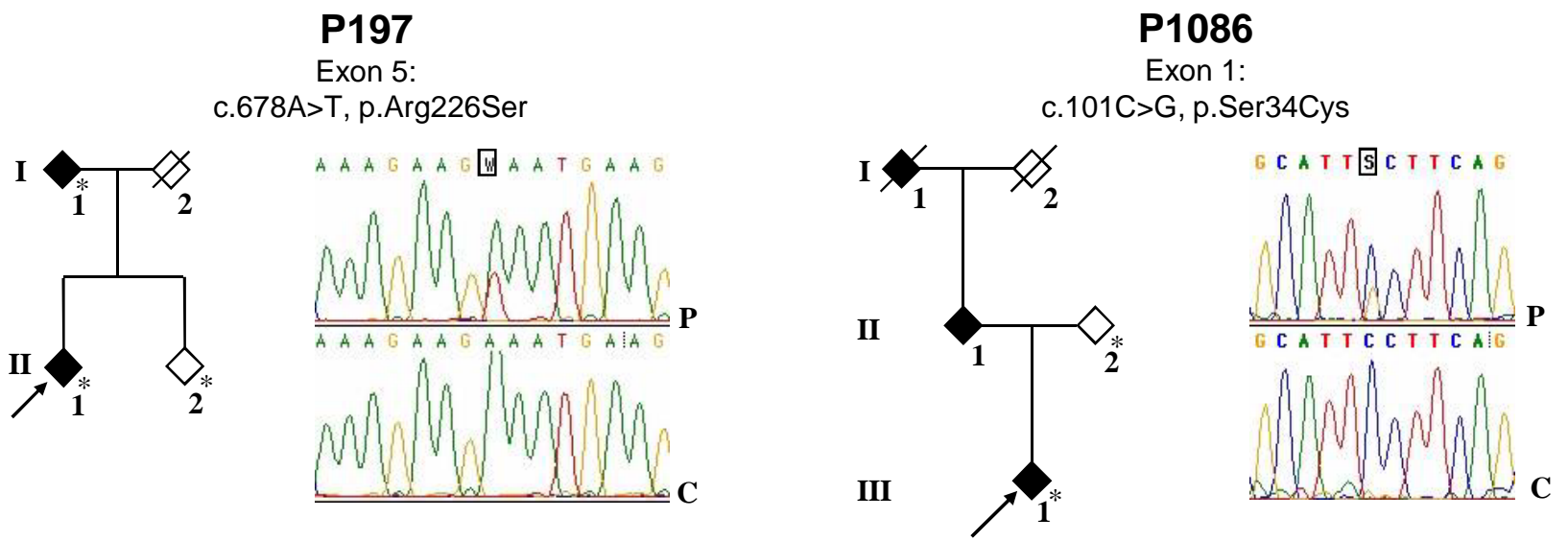

P227

Exon 1:

c.23delAG, p.Gly10GlufsX14;
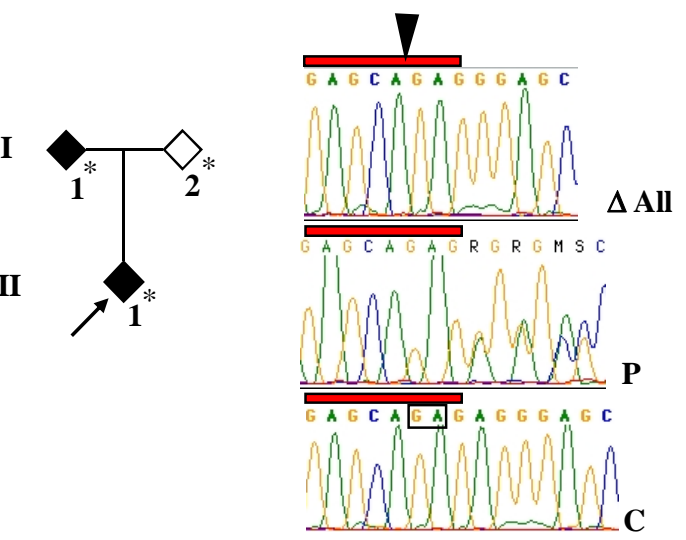

\begin{tabular}{|c|c|c|c|c|}
\hline \multirow{2}{*}{$\begin{array}{c}\text { Patient } \\
\text { ID }\end{array}$} & Mutation & \multicolumn{2}{|c|}{ Protein } & $\begin{array}{c}\text { Other exonic } \\
\text { variants }\end{array}$ \\
\cline { 3 - 4 } & & POLYPHEN & SIFT & \\
\hline P197 & c.678A>T & $\begin{array}{c}1.927 \\
\text { (possibly damaging) }\end{array}$ & $\begin{array}{c}0.01 \\
\text { (affect protein function) }\end{array}$ & \\
II-I/I-I & p.Arg226Ser & c.101C>G & 1.924 & 0.00 \\
P1086 & c.1pssibly damaging) & (affect protein function) & \\
\hline III-I/II-I/I-I & p.Ser34Cys & & & p.Gly269Arg \\
\hline P227 & c.23delAG & & & \\
II-I/I-I & p.Gly10GlufsX & & & \\
\hline
\end{tabular}

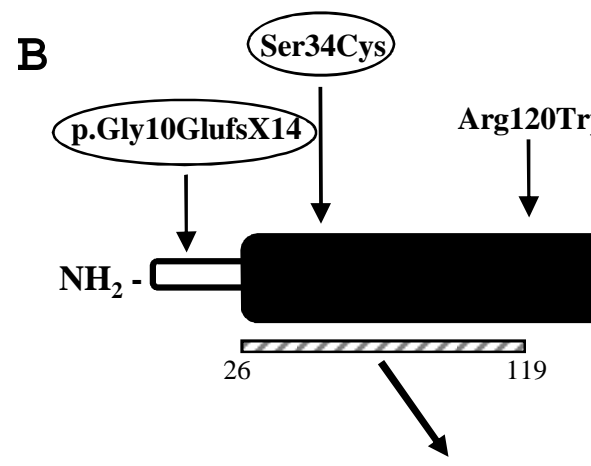

DOMAIN I

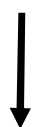

GLUTATHIONE BINDING SITE

Thr157Pro Arg226Ser

GIn218Glu|Cys240Tyr

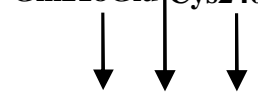

GST

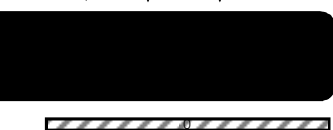

\section{HD1}

210

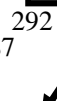

292 / 309

TMD

-COOH

DOMAIN II

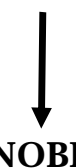

XENOBIOTIC

SUBSTRATES
MITOCHONDRIAL MITOCHONDRIAL FISSION
TARGETING 